\title{
Effect of Hyperglycemia on Immune Function
}

\author{
Khadija Ansari and Deepak Chandra* \\ *Department of Biochemistry, University of Lucknow, India
}

Submission: January 18, 2018; Published: August 31, 2018

*Corresponding author: Deepak Chandra, Department of Biochemistry, University of Lucknow, Lucknow, India, E-mail: deepakvns@yahoo.com

\section{Editorial}

Diabetes Mellitus (DM) is a metabolic disorder which leads to many serious secondary complications like retinopathy, neuropathy, nephropathy, cardiovascular complication, delayed wound healing etc. Diabetics are more prone to infection due to compromised immunity. Hyperglycaemia leads to oxidative and osmotic stress. This short communication is the preliminary study to know the effect of high glucose concentration (mimicking hyperglycemia) and $\mathrm{H}_{2} \mathrm{O}_{2}$ (mimicking oxidative stress) on murine macrophage cell line RAW 264.7.

\section{Methodology}

RAW cell line was procured from NCCS Pune and maintained in RPMI 1640 media with 10\% Fetal Calf Serum (FCS) and antibiotic (penicillin and streptomycin) at $37{ }^{\circ} \mathrm{C}$ and $5 \% \mathrm{CO}_{2}$ in $\mathrm{CO}_{2}$ incubator. 5X104 cells were seeded in each well of 24 well plate, kept in serum free media overnight followed by replacement with serum containing media and treatments (different glucose and $\mathrm{H}_{2} \mathrm{O}_{2}$ concentration). Cells were incubated for different time intervals. Supernatant was collected for cytokine estimation by ELISA kit. Viability of cells was estimated by cell MTT assay.

\section{Result and discussion}

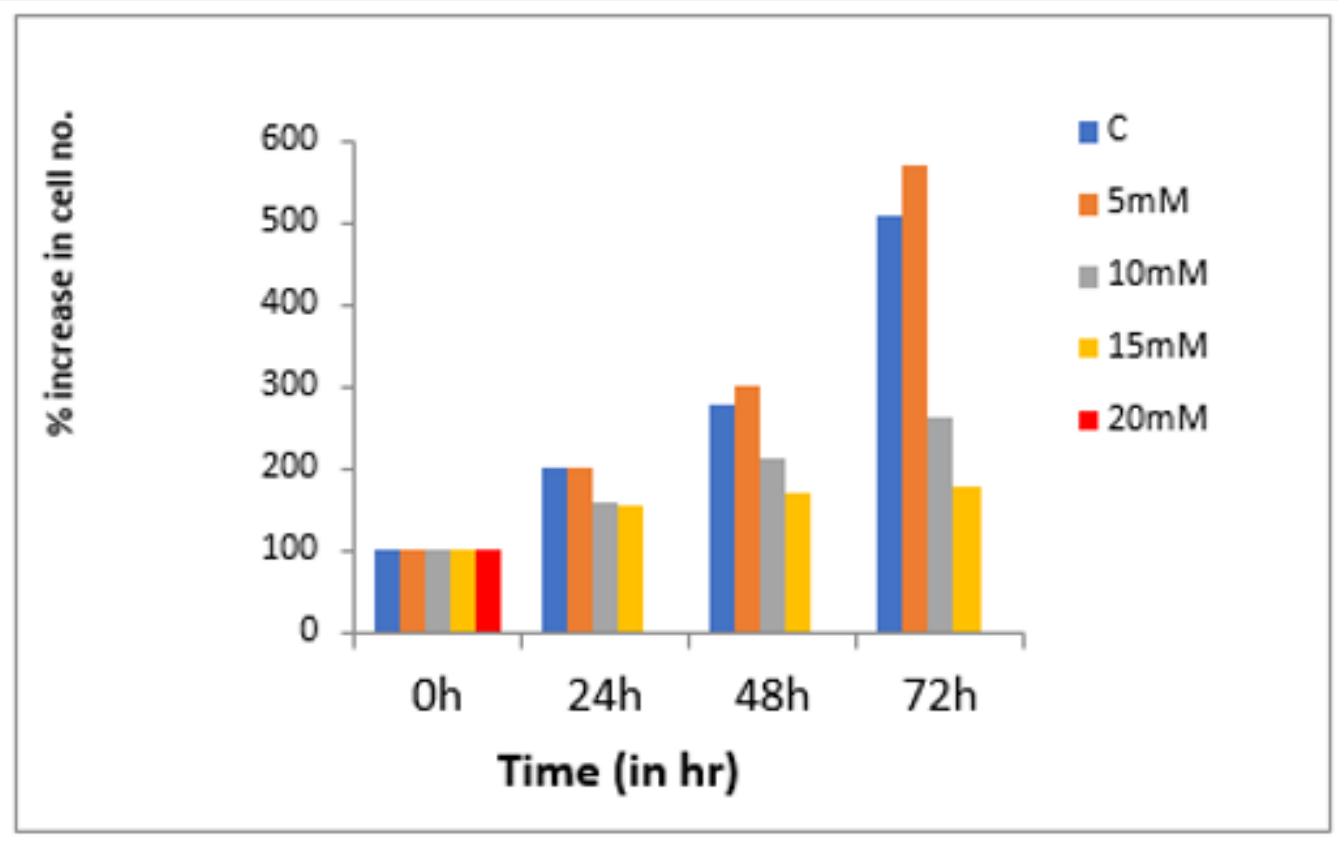

Figure 1: MTT assay. 
Macrophages play crucial role in connecting innate immunity (by phagocytosis) and cell mediated immunity by secreting different cytokines which may have immune stimulatory and immune suppressive functions. The osmotic stress induced inhibition in the growth of macrophage cell line, which was found to be time and concentration dependent (Figure 1). Lipopolysaccharide (LPS) is the major component of the outer membrane of Gram-negative bacteria used for the activation of macrophages. Lipopolysaccharide (LPS) has significant positive inductive effect on the growth of macrophage cells (Figure 2). LPS resulted in increased levels of immuno-stimulatory cytokines IL-4 (Figure 3) and IL-6(Figure 4). No significant change in IL-10 level was seen (Figure 5). Osmotic stress leads to compromised immunity. The macrophagic cell line when subjected to oxidative stress showed a considerable decrease in cell count (as observed by MTT assay) with increase in concentration (from $25 \mu \mathrm{M}$ to $50 \mu \mathrm{M} \mathrm{H}_{2} \mathrm{O}_{2}$ concentration). Cell death was observed at $100 \mu \mathrm{M}$ $\mathrm{H} 2 \mathrm{O} 2$ concentration (data not shown). Results showed that LPS had a positive inductive effect on the cell culture and the cell count increased considerably (Figure 6 \& 7). In oxidative stress the interleukins had an immunomodulatory effect on the cells. Increased IL-4 (Figure 8), IL-6 (Figure 9) and TNF- $\alpha$ (Figure 10) suggests immuno-proliferative effect while IL-10 (Figure 11) suggests immunosuppressive effect. In osmotic stress there was no significant change in GSH levels in control and stressed cells. There was a sharp decline in GSH level in presence of $\mathrm{H}_{2} \mathrm{O}_{2}$ when compared to control (data not shown). Moreover, LPS presence didn't make any observable change in result. This suggests that treatment with $\mathrm{H} 2 \mathrm{O} 2$ resulted in oxidative stress.

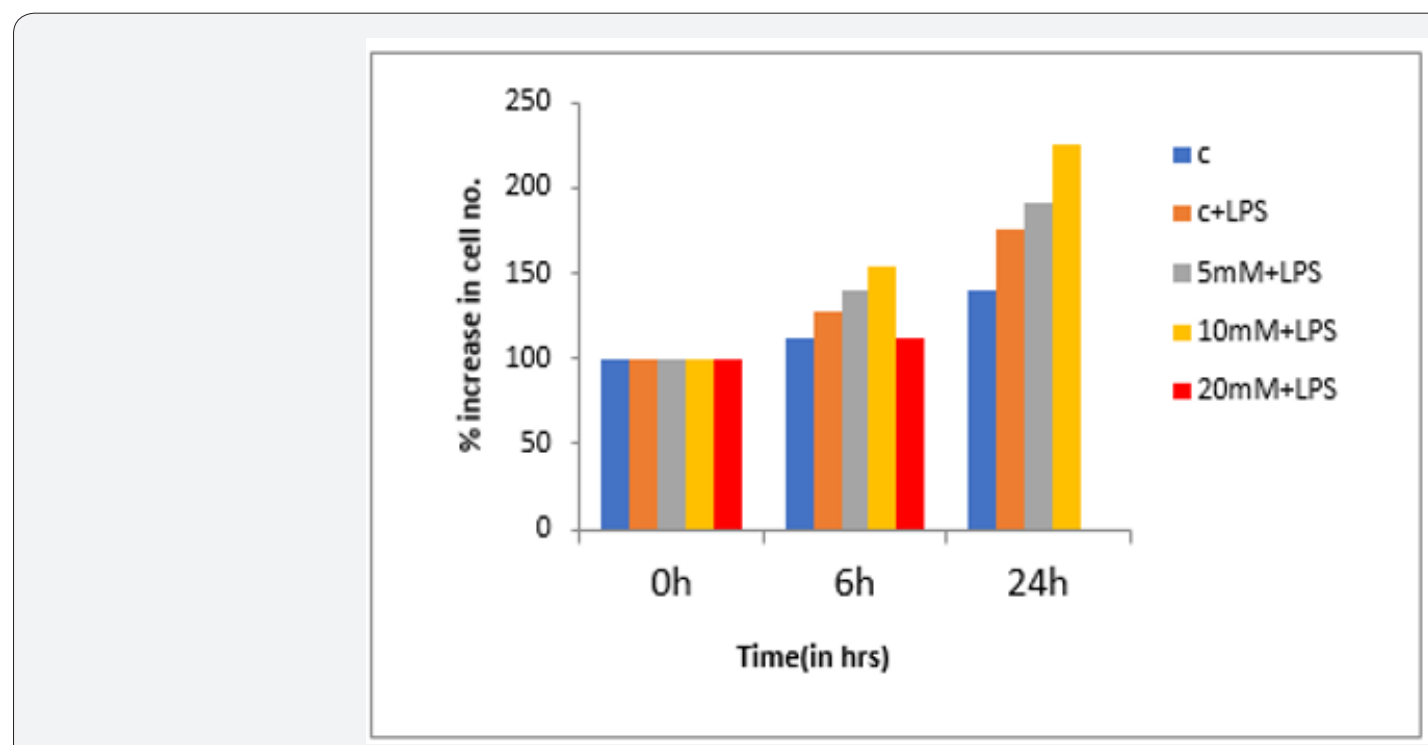

Figure 2: MTT assay.

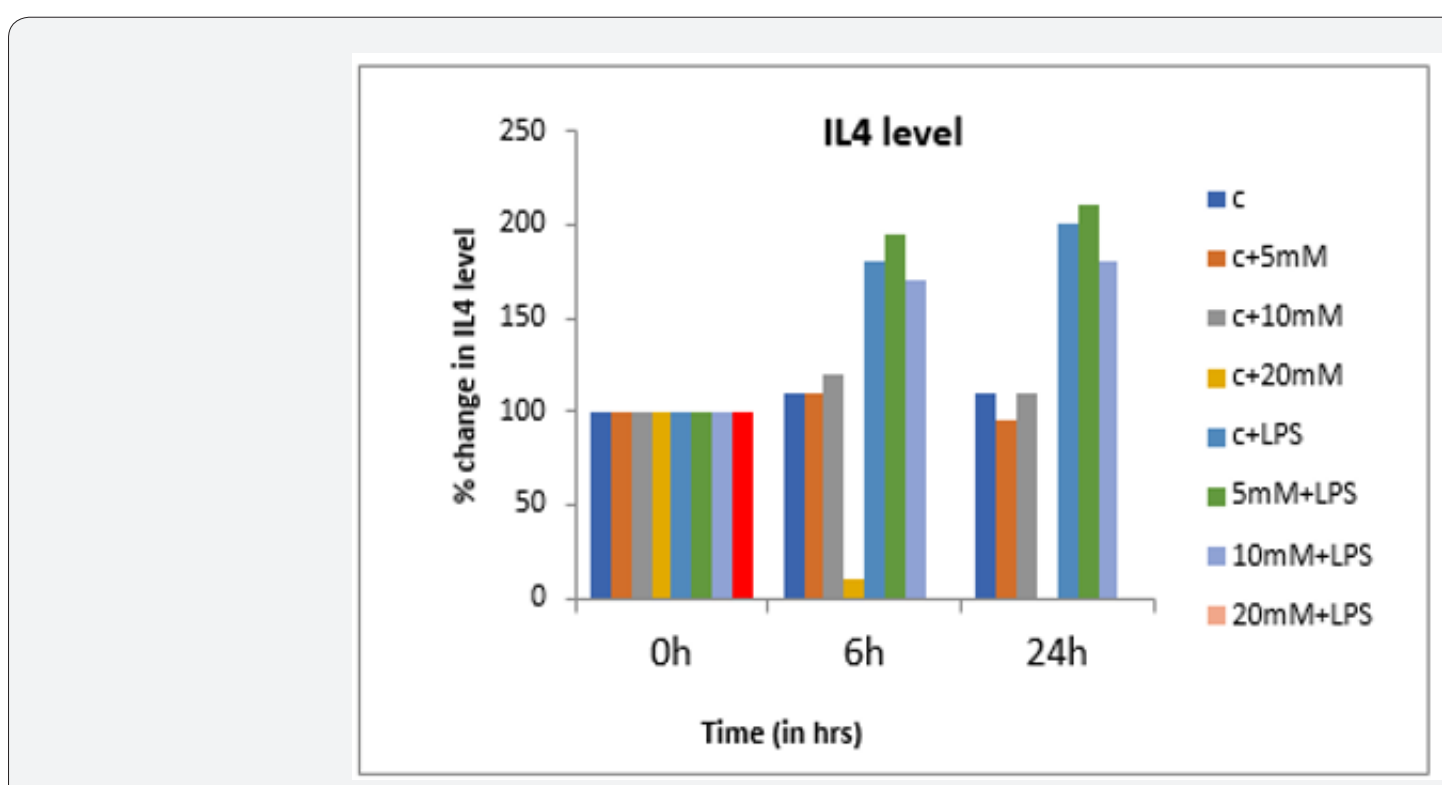

Figure 3: IL-4 level. 


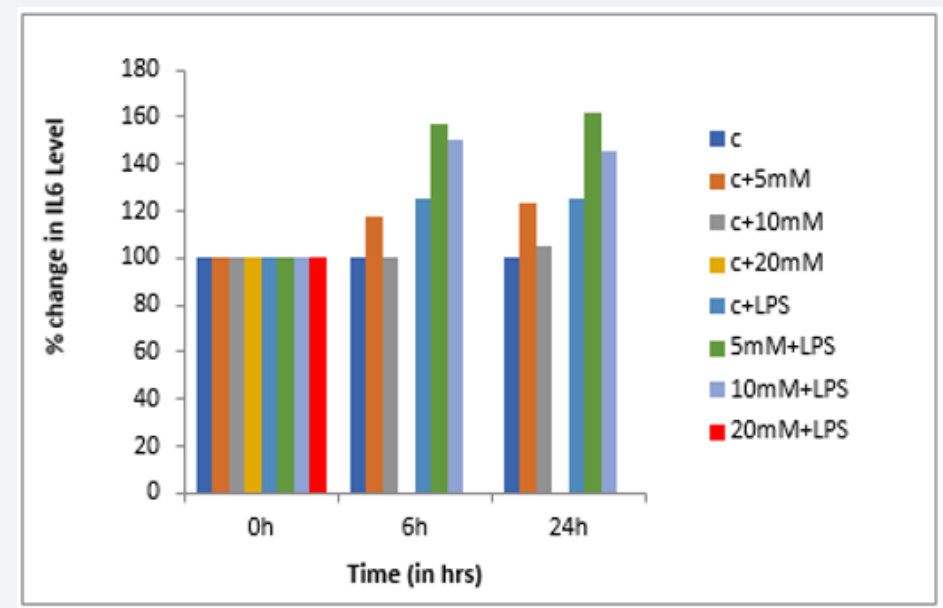

Figure 4: IL-6 level.

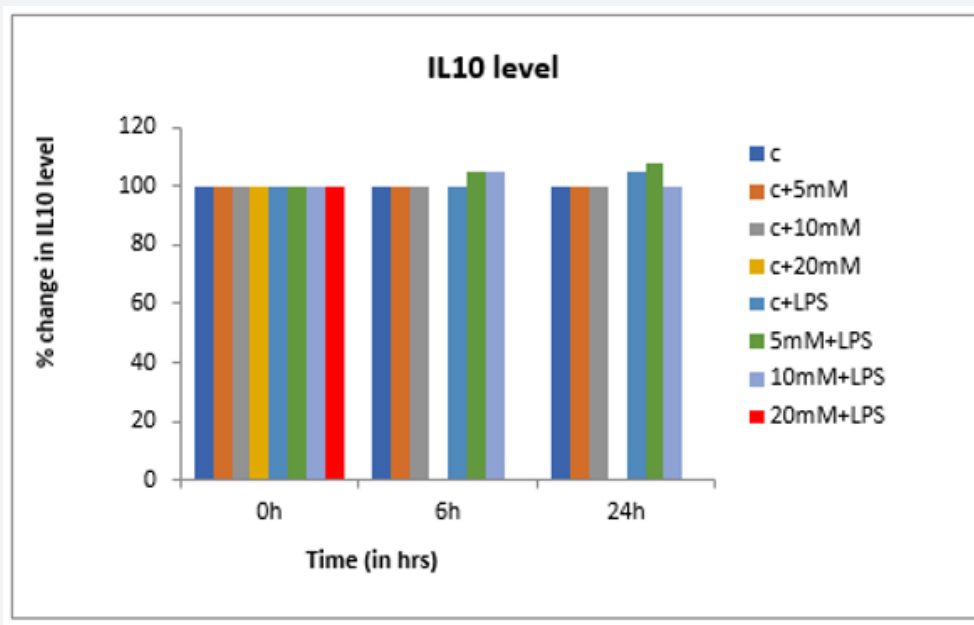

Figure 5: IL-10 level.

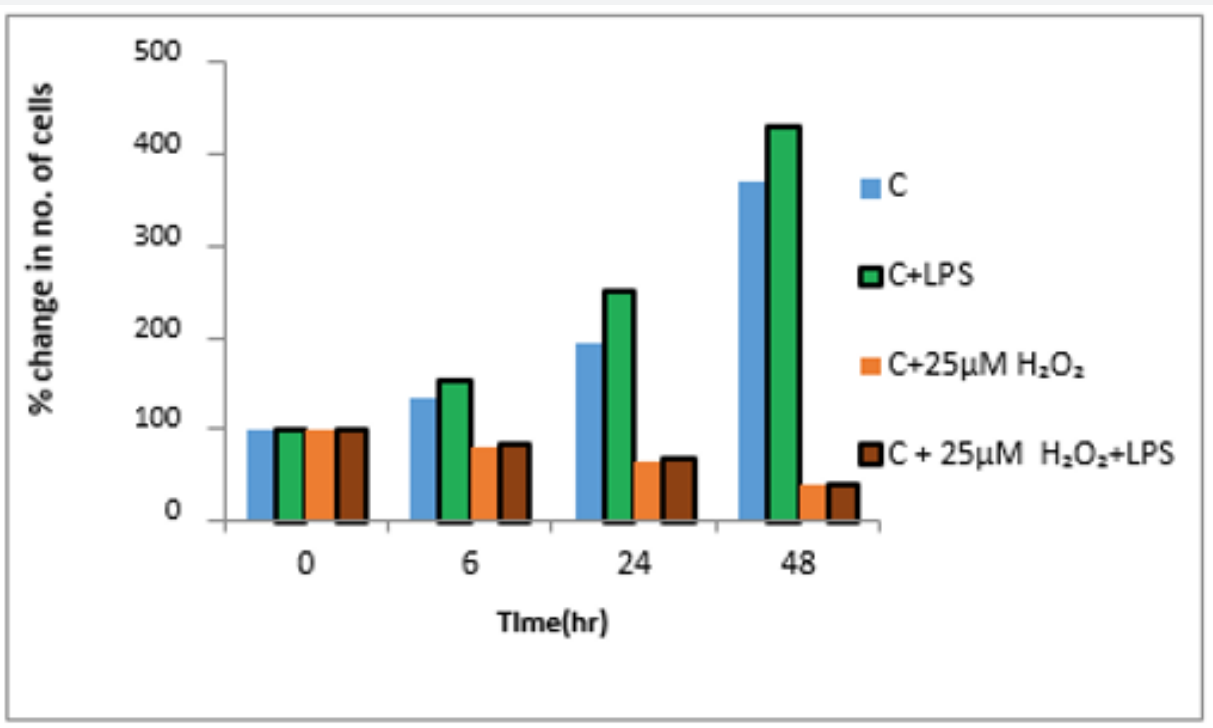

Figure 6: $25 \mu \mathrm{M} \mathrm{H} 2 \mathrm{O} 2$. 


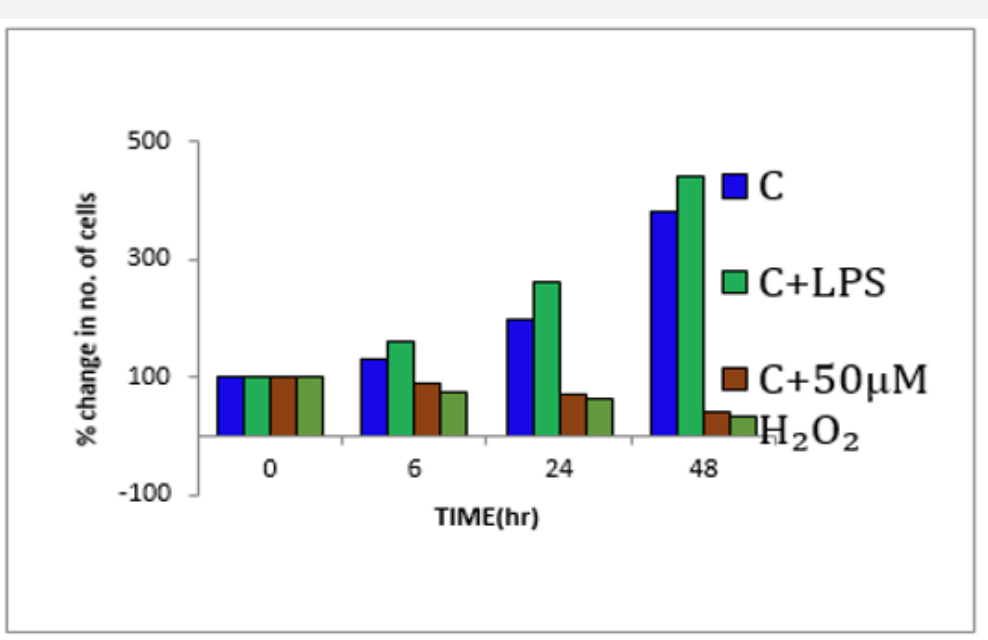

Figure 7: $50 \mu \mathrm{M} \mathrm{H} 2 \mathrm{O} 2$.

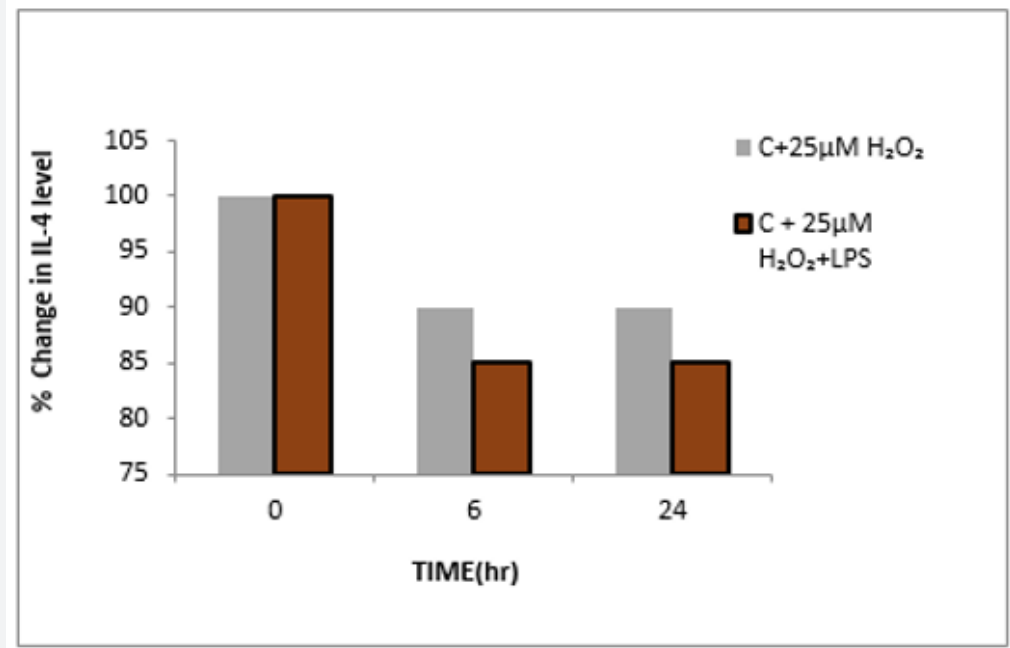

Figure 8: IL-4 level.

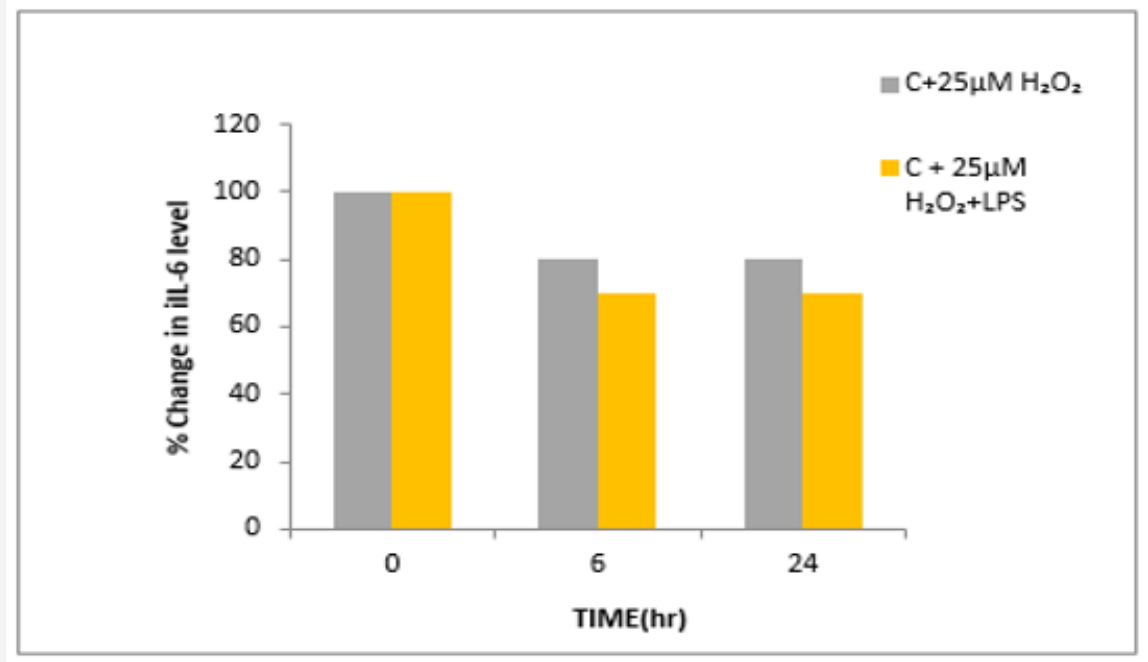

Figure 9: IL-6 level. 


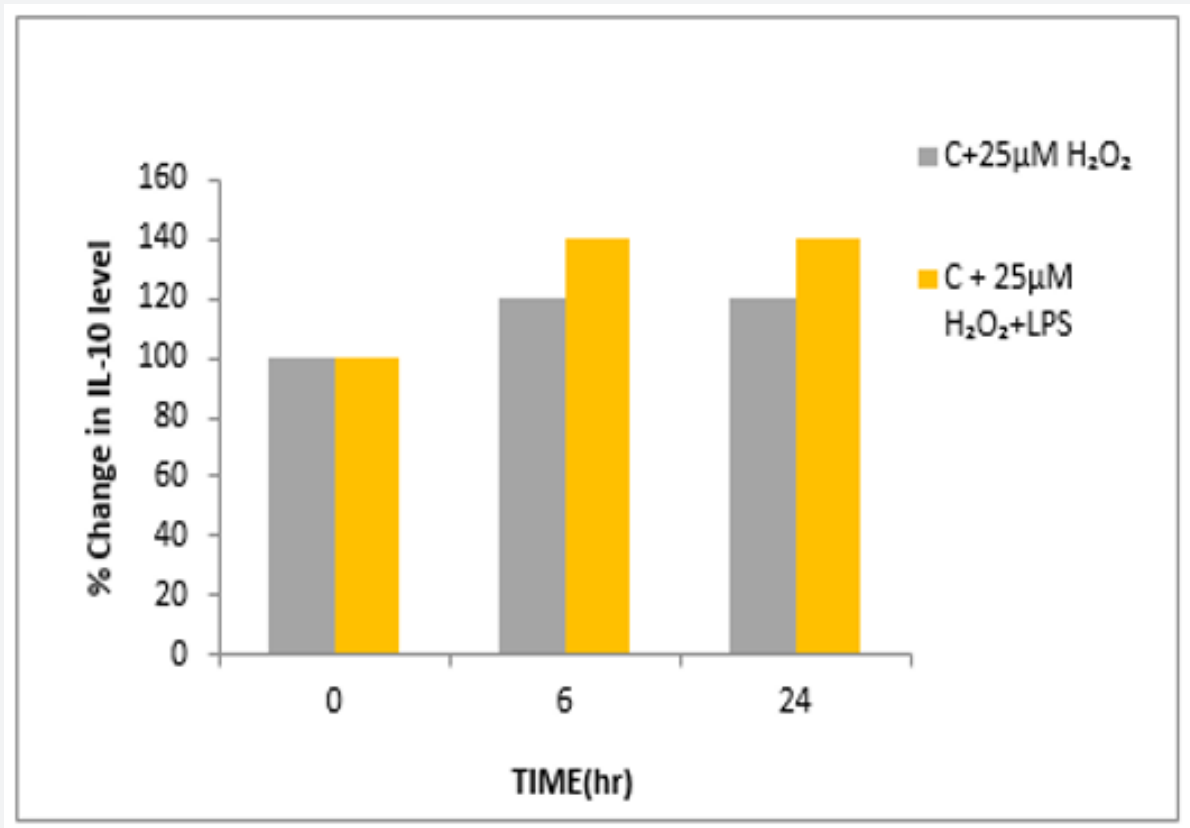

Figure 10: IL-10 level.

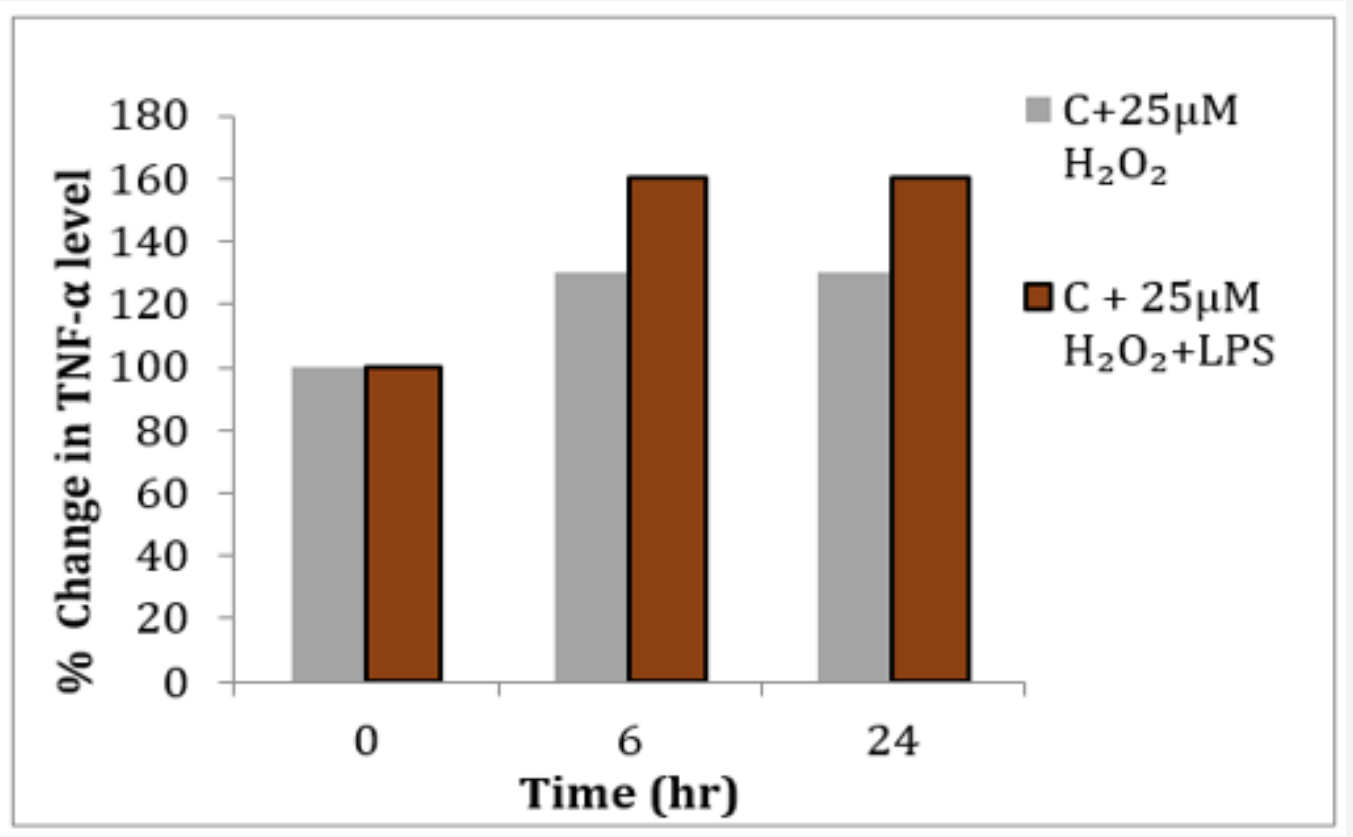

Figure 11: TNF- $\alpha$ level.

Our findings suggest that upon osmotic and oxidative stress the levels of immuno-proliferative cytokines (IL-4, IL-6, TNF- $\alpha$ ) decreases while immune-suppressive cytokine IL-10 increases resulting in macro phage dysfunction. This may be the basis of immune compromised state in oxidative stress mediated disease for example Diabetes. 
This work is licensed under Creative Commons Attribution 4.0 Licens

DOI: 10.19080/AIBM.2018.10.555792
Your next submission with Juniper Publishers will reach you the below assets

- Quality Editorial service

- Swift Peer Review

- Reprints availability

- E-prints Service

- Manuscript Podcast for convenient understanding

- Global attainment for your research

- Manuscript accessibility in different formats ( Pdf, E-pub, Full Text, Audio)

- Unceasing customer service

Track the below URL for one-step submission https://juniperpublishers.com/online-submission.php 